Images in...

\title{
Bladder urothelial fissures: a reminder of a distressing disease
}

Antoine Kass-lliyya, Rupert Beck, John lacovou

Urology Department, Great Western Hospital, Swindon, UK

Correspondence to Mr Antoine Kass-lliyya, antoine.kass@gwh.nhs.uk

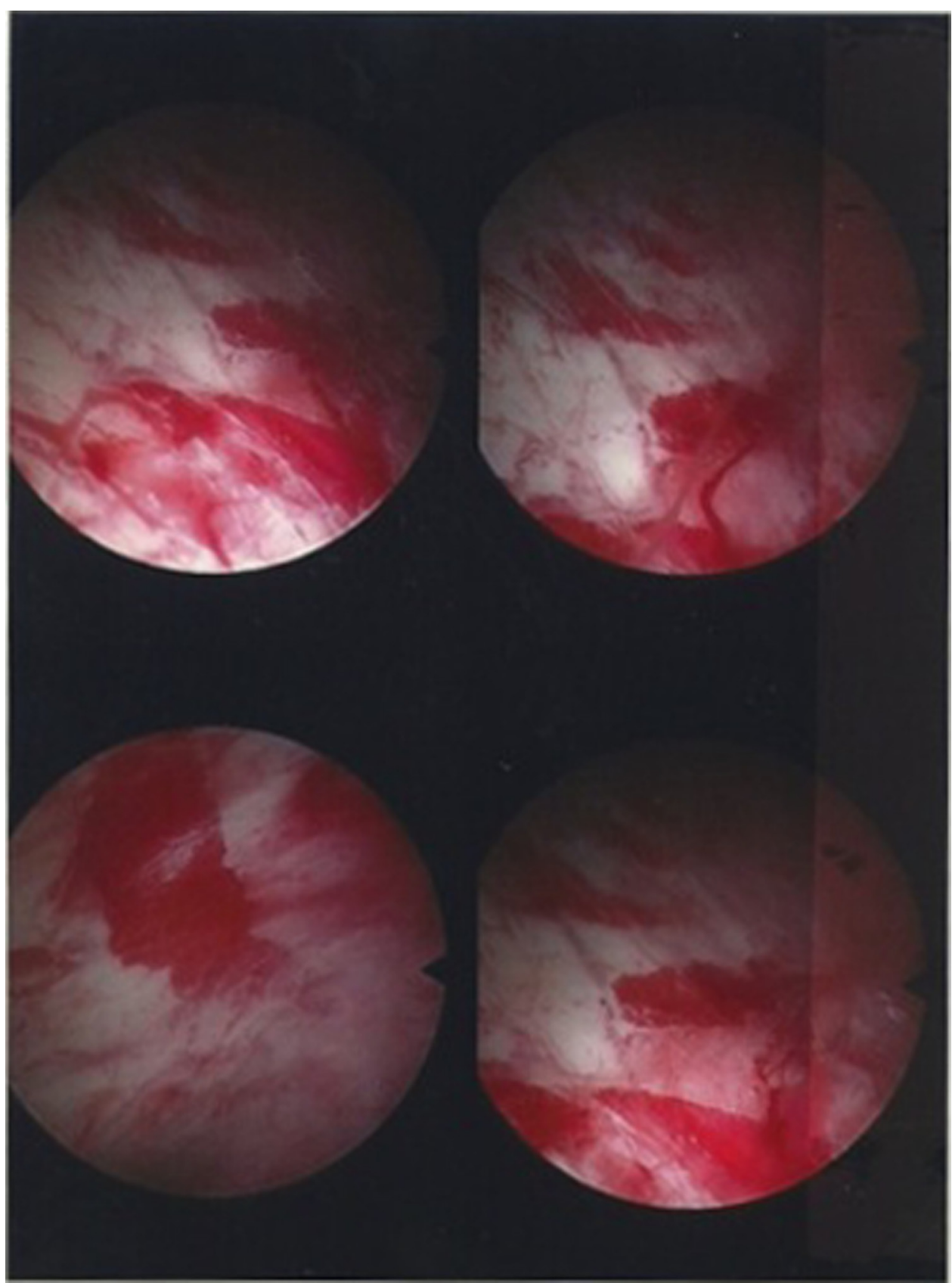

Figure 1 Upper two pictures and lower left picture: multiple urothelial cracks seen after hydrodistension, lower right picture: glomerulation (petechiae). 


\section{BMJ Case Reports}

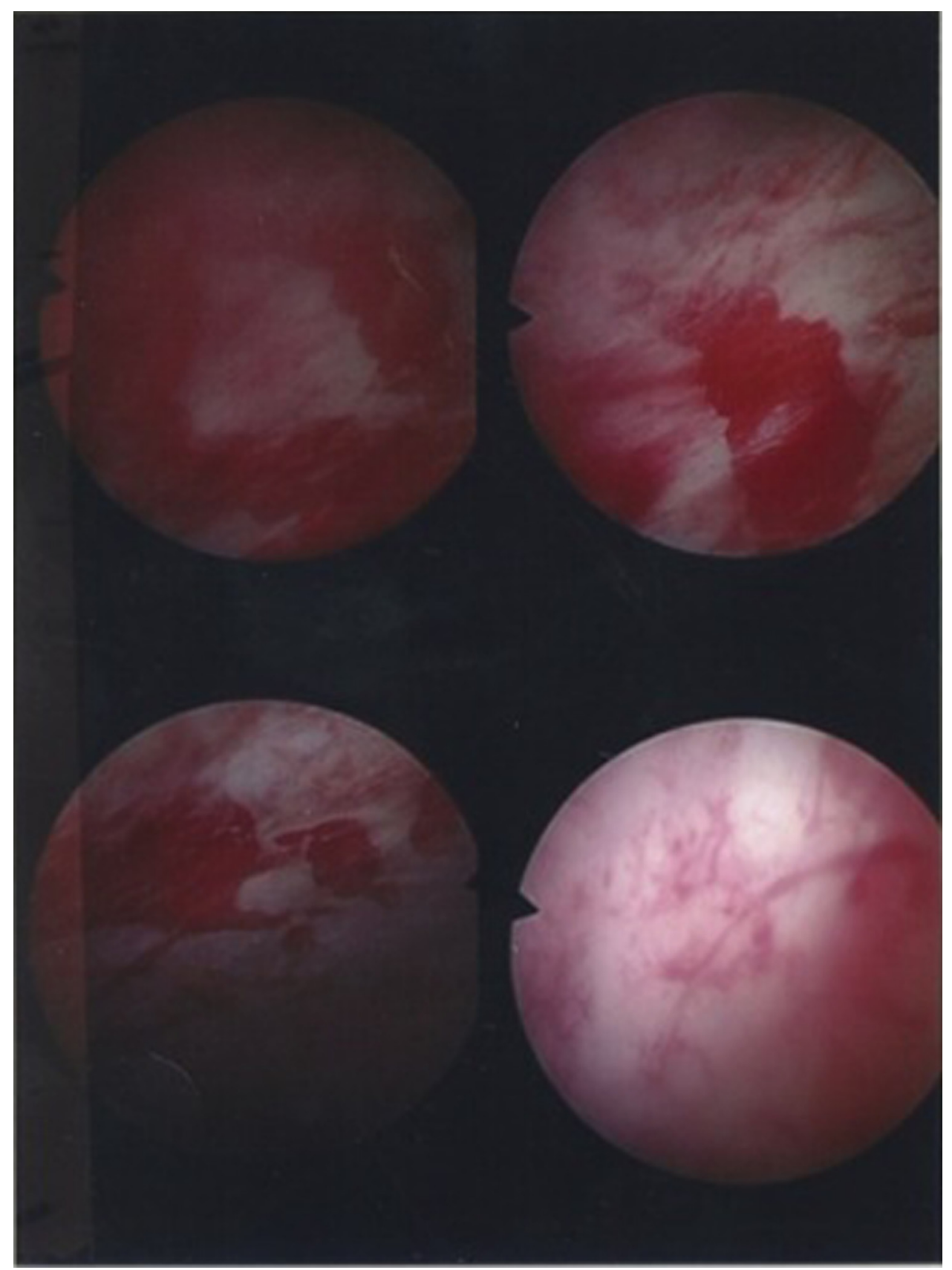

Figure 2 Further urothelial cracks seen after hydrodistension.

\section{DESCRIPTION}

A fit middle-aged lady was referred to the urology clinic with intractable, irritative urinary tract symptoms and lower abdominal pain. Investigations did not reveal any evidence of urinary tract infections. Initial empirical treatment with anticholinergics failed to offer symptomatic relief. Subsequent urodynamic investigations were aborted due to the patient's inability to tolerate bladder filling. An ensuing cystoscopy and bladder biopsy suggested the diagnosis of interstitial cystitis (IC); a chronic refractory bladder disorder characterised by urinary frequency, nocturia, urgency and bladder pain. ${ }^{1}$ A decision was made to offer the patient a cystodistension as a recognised treatment modality. Figures 1 and 2 show images obtained during cystoscopy after filling the bladder with $500 \mathrm{ml}$ of isotonic fluid. Glomerulations (petechiae), seen as discreet, tiny, raspberry like lesions, figure 2 (right lower picture) and urothelial fissures or cracks, figures 1 and 2 (the remaining pictures), helped confirm the clinical suspicion. The cause of IC is still unknown. It is a diagnosis of exclusion - other possible pathological causes should be considered, (eg, drugs, TB, or radiation induced cystitis, overactive bladder). ${ }^{2}$ Treatment options include behavioural therapy, oral medications (tricyclics, antihistamines), repeated intravesical drug installation (dimethyl sulphoxide, sodium hyaluronate), nerve stimulation and surgery (hydrodistension, urinary diversion). ${ }^{3}$

Competing interests None.

Patient consent Obtained. 


\section{REFERENCES}

1. Abrams P, Cardozo L, Fall M, et al. The standardisation of terminology of lower urinary tract function: report from the Standardisation Sub-committee of the International Continence Society. Neurourol Urodyn 2002;21:167-78.
2. Reynard J, Brewster S, Biers S. Oxford Handbook of Urology. UK: Oxford University Press 2009.

3. Lukban JC, Whitmore KE, Sant GR. Current management of interstitial cystitis. Urol Clin North Am 2002;29:649-60.

This pdf has been created automatically from the final edited text and images.

Copyright 2012 BMJ Publishing Group. All rights reserved. For permission to reuse any of this content visit http://group.bmj.com/group/rights-licensing/permissions.

BMJ Case Report Fellows may re-use this article for personal use and teaching without any further permission.

Please cite this article as follows (you will need to access the article online to obtain the date of publication).

Kass-lliyya A, Beck R, lacovou J. Bladder urothelial fissures: a reminder of a distressing disease. BMJ Case Reports 2012; 10.1136/bcr.10.2011.5009, Published XXX

Become a Fellow of BMJ Case Reports today and you can:

- Submit as many cases as you like

- Enjoy fast sympathetic peer review and rapid publication of accepted articles

- Access all the published articles

- Re-use any of the published material for personal use and teaching without further permission

For information on Institutional Fellowships contact consortiasales@bmjgroup.com

Visit casereports.bmj.com for more articles like this and to become a Fellow 